\title{
The Plight of Informal Settlers in the Coastal Areas of Panabo City: A Basis for Intervention
}

\author{
Anthony John O. Montiel ${ }^{1}$, Sherry Jean B. Capuyan ${ }^{2}$, Jefferson H. Silverio ${ }^{3}$, Melcris J. Olayer ${ }^{4}$, Shynar P. \\ Abiera $^{5}$, Ronel G. Dagohoy ${ }^{6}$ \\ ${ }_{1,2,3,4,5}$ Student, Bachelor of Public Administration, Davao del Norte State College, Philippines \\ ${ }^{6}$ Program Chairperson, Bachelor of Public Administration at Institute of Leadership, Entrepreneurship and Good Governance, \\ Davao del Norte State College, Philippines
}

\begin{abstract}
As urban areas flourished, informal settlements doubled their numbers in slew. Its manifestation is the influx of urban poor living in environmentally risky parts of the city, such as coastal areas. Aside from having a compromised settlement, their vulnerability to different hazards was prevalent. This study unfolds the plight of the informal settlers in coastal areas of the barangays Cagangohan, J.P. Laurel, and San Pedro of Panabo City; and their coping mechanisms used in dealing with the challenges in their everyday life. This inquiry used the qualitative case study research method to describe, elicit discussion, and analyze a particular situation. This has been understood through in-depth interviews with the informal settlers living along the coastal area for at least one year; and series of analyses made by the researchers. Through the data gathered, there were six (6) emerging themes extracted. These themes were the living condition predicaments, environmental health risks, struggles in family and livelihood instability, practicality and resiliency, resources utilization, and emergency tactics. This study proposes a basis for the understanding of the life experiences of informal settlers and formulation of various interventions in response to the problems, and upgrading projects for the betterment of the informal settlers; that will be undertaken in the future.
\end{abstract}

Keywords - Coastal Areas, Informal Settlers, Living Condition, Case Study, Philippines

\section{INTRODUCTION}

\subsection{Rationale}

$\mathrm{T}$ he risk of living through the daily needs to survive is now getting worse in every part of this world, especially in coastal areas in the Philippines. The spread of informal settlements has become a phenomenon associated with big cities and expanding urban centers in the Philippines. Informal settlers living in dangerous areas like riverbanks and shorelines are part of the estimated number of informal settlers in the country that varies, ranging from as low as 470,000 families to as high as 2.5 million families from the early $1970 \mathrm{~s}$ to more recent years due to rapidly urbanized cities [1]. It is defined that informal settlers are also called/known by squatter settlement that depends on their country residing in. They are commonly residing in the urban settings; they classified informal settlers as very poor, no access to lands that they can call their own can define a residential area that has developed without legal claims to the land and without permission from the person authorized to build and in their illegal or semi-legal status, infrastructure and services are usually inadequate. In addition to income poverty, informal settlers confront daily social and economic exclusion, as well as exposure to health risks and life-threatening conditions [2].

During 2008 and 2013, there are 165 million inhabitants displaced by disasters brought on by natural hazards, with an average of 27 million a year [3]. Urban displacement associated with disasters is estimated to rise in the coming decades, as quick and unplanned urbanization continues to boost and hazards become more frequent and intense. Informal settlers are more exposed and vulnerable to natural hazards than the wide-ranging population. Because they tend to live in insubstantially, makeshift shelters in at-risk areas, they are more expected to be affected and displaced by disasters [3]. Invasive personal hazards and economic insecurity scheme to create a condition of unyielding vulnerability for poor urban residents. Unsatisfactory housing and insecurity of tenure take much of the comfort out of having a 'home' in the city, and narrow access to basic services such as clean water and hygiene facilities exposes poor urban inhabitants to disease [4]. Under the said statements, it is affirmed by some authors that Climate change is placing increasing pressure on coastal regions, which are already seriously affected by intensive human activity. Roughly more than 200 million people worldwide live along coastlines less than five meters above sea level. By the end of the 21st century, this figure is estimated to increase to 400 to 500 million [5]. People who live in coastal areas lack pure drinking water, which aggravated the spread of waterborne diseases in the affected areas; even the main 249 sources of infectious diseases are polluted and highly saline water [6]. Children and the elderly were found most vulnerable during the cyclone. They are vulnerable due to health and physical vulnerabilities, and most children are also suffering from health problems such as malnutrition, and people with mental health problems increased dramatically [6].

Moreover, living with poor sanitation and lack of potable water, similarly to restricted access to health and education services, means that an associate array of appalling sicknesses usually strikes occupants. It is best known that poor internal housing conditions exacerbate facilitate illness and unhealthiest. There are various studies that most of the 
informal have not enough income to install decent water systems [7].

The informal settlers in the Philippines are growing from time to time, and it appears to be the biggest among the ASEAN (Association of Southeast Asian Nations) countries [8]. It was estimated in the Philippines that 44 percent of the population lives in urban areas. In excess of 40 percent of the country's 1.4 million informal settlers are in the capital and mega-city, Metro Manila, where 544,000 families reside in informal settlements. While many settlements also exist in rural areas, this urban number is expected to grow over the year [9]. In Davao, 26 out of the 182 barangays are in coastal areas. Notably, 43 percent or 104,204 households out of the total 240,057 households in the city living in the coastal areas are directly dependent on the resources of the sea for their survival [10]. The barangay of Panabo has informal settlers with 85 percent in urban land, illustrating the preference of informal settlers to locate in urban areas where the means of livelihood abound [11].

Moreover, in the Philippines, typhoon Pablo slammed into eastern Mindanao and the Visayas on the fourth of December; in region XI, at least 253 died, and 56,000 people fled their homes in fear of the worst storm to hit the Philippines in 2012. Davao Oriental saw 395 dead, mainly from the coastal towns of Cateel and Baganga, where the typhoon had made landfall [12].

However, as the stated information above, there has been a problem with informal settlers living along with the coastal areas. Many studies are discussing the different aspects of living in an informal settlement. But they are not that sufficient in delving the challenges they have encountered in their day-to-day living, especially to the informal settlers living along with the coastal areas of Panabo City. Living in informal settlements leads to the exposure and vulnerability to environmental hazards to people and the land which they occupy. This study proposes as the basis for formulating various interventions in achieving sustainability and upgrading projects for the betterment of the informal settlers; that will be undertaken in the future.

\subsection{Research Questions}

This study seeks to identify the difficulties of informal settlers; specifically, this ought to answer the following research questions:

1. What are the challenges of informal settlers living in the coastal area?

2. What are the coping mechanisms they employ in dealing with their challenges?

3. What government interventions can be made in addressing the challenges of living in the coastal area?

\subsection{Theoretical Lens}

This study is anchored to the Concentric Zone Theory by Burgess and Park (1925), a study of urban ecology. This is a theory of urban land-use patterns. The land is one of the scarce urban resources which led to competition between groups and eventually urban space division into distinctive natural areas in which people shared similar social characteristics because they were subject to the same ecological pressures [13]. This theory meant that because of the different income levels of other ethnic groups who competed for desirable and valuable land, Informal settlements belonged to residential differentiation. Additionally, the Local Government Code of 1991 and the Urban Development Housing Act of 1992. Local Government Units (LGUs) are supposed to provide housing projects for the acquisition of real property in accordance with Section 297 (a) of RA 7160 (Local Government Code of 1991) [14]. In connection to the theory, the said law is meant for this study because it aims to provide a framework for the implementation of a comprehensive and sustainable urban development and housing program. As specified in Section 29 of this act, the local government, in collaboration with the National Housing Authority, shall ensure relocation and resettlement sites with social services and amenities, as well as access to jobs and livelihood opportunities, adequate to meet the basic needs of affected individuals [15]. Furthermore, it aims to provide extra attention to homeless citizens, also identified as informal settlers; some certain rules and protocols must be met in the case of demolition [16].

\subsection{Significance of the Study}

This study was conducted to discover the precarious situation of the informal settlers living along with the coastal areas of Panabo City, Davao del Norte. In addition, this research observed the condition as a basis for intervention that unfolds the informal settler's life. Moreover, the success of this research will be beneficial to the following:

Government: This study will serve as their basis in making interventions and generate relevant information which can be of use not just limited to the public and private administrators and human resource managers but, most importantly, to policymakers. Furthermore, the findings from this study can spark evidence-based information which can be used by various government agencies.

Informal Settlers: This study will serve as their opportunity to assert their sentiments and experiences in living in the coastal areas.

Future Researcher: This study will serve as a basis to have new knowledge in understanding the life experiences of informal settlers in coastal areas. This will also serve as their future reference in conducting similar to the study.

\subsection{Scope and Delimitations}

This case study was delimited only to the informal settlers that are currently residing in the coastal areas of the City of 
Panabo, Davao del Norte. These were the people aged 20 and above; they must have at least one year of residing along the coastline; have no pertinent documents, proof, or consent of tenancy from the owner of the property they currently live; must be physiologically and psychologically capacitate to be interviewed.

\subsection{Definition of Terms}

The following terms are operationally used in this study and hereby defined to provide thorough understanding to the readers:

Coastal Area. It is a particular region located at the shore of a large body of water (sea or an ocean). For this study, it is particularly identified and located at the Barangay Cagangohan, San Pedro, J.P. Laurel at the City of Panabo, Davao del Norte.

Informal Settlers. These are people residing in a certain area that have no official ownership within their reputed domain. In this study, most of them were found along the coastline and have no official pertinent records granting them to stay in the area in which they are currently living.

\section{METHODOLOGY}

This part presented the methods and procedures on how the study is conducted. This includes sections on research design, research locale, research participants, data collection procedure, data analysis, and the ethical consideration in conducting research.

\subsection{Research Design}

The researchers employed a qualitative research design in the form of an "In-depth Interview" (IDI) to gather relevant information. To begin with, a qualitative study must use assumptions and a theoretical framework that is inclined to study the research problems in asserting the significant individuals or groups contributing to accenting the research problem [17]. In addition, qualitative research uses the process of naturalistic inquiry in seeking an in-depth understanding of social phenomena within a natural setting [17]. The "Why's" of the social phenomena and direct experiences of human beings are used as meaning-making agents. It is designed to reveal the meaning that informs the actions or outcomes that quantitative research typically measures [18].

On this note, a case study was used to investigate the difficulties, challenges, and strategies of the informal settlers living along the coastal area. A case study is a type of qualitative research that is derived from an investigation. The researchers/investigators explore the life and in-depth data collection that includes different sources of information (observation, interviews, audio materials, and documents and reports) [19]. A qualitative case study is a type of research that enables an exploration of a certain phenomenon within its context using different data sources [20]. This type of analysis gives opportunities to the researchers to explain a situation and explore an event and gives opportunity to the informants to express their opinions and views on the issues presented. Also, purposive sampling is used in this study and is typically focused on small samples. Purposive sampling also focuses on the selection of informants that are information-rich casesthose who have further knowledge about the issues that the research focuses on [21].

\subsection{Research Locale}

The study was conducted in Panabo City, Davao del Norte. Panabo is a coastal component city in the province of Davao del Norte.

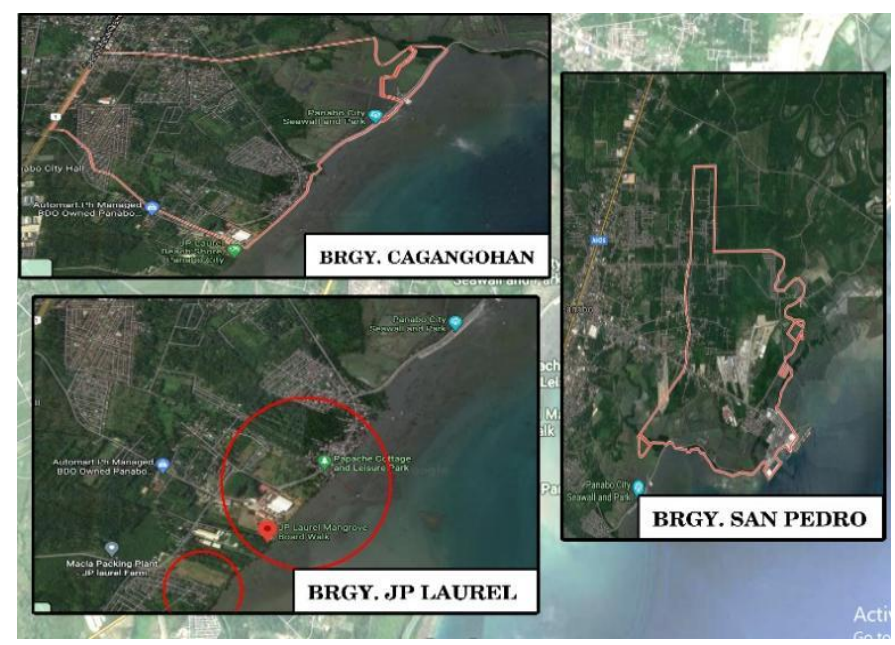

Figure 1: Map of the Davao del Norte where the Barangays in Coastal Areas of Panabo City is located, and the study was conducted.

Being a third-class city in the province of Davao del Norte, it has forty (40) barangays, which a total estimated population of 184,599 , this presented $18.16 \%$ of the total population of Davao del Norte with an annual growth rate of $1.09 \%$ from 2010 to 2015 [22]. The researcher determines three barangays as the subject of the study.

The researchers choose Barangay Cagangohan and San Pedro as the focus of the study, which are recognized as coastal barangays that are moderately vulnerable, also barangay JP Laurel that has a low level of susceptibility to natural hazards [23]. Lastly, the design covered the living condition, difficulties and challenges, strategies, and their insights as used by six (6) informal settlers from the three coastal barangays that have been chosen; each barangay has two (2) informants.

\subsection{Research Participants}

In this study, purposeful sampling was used in the selection of informants. Purposeful sampling is also known as judgmental sampling, a non-probability sampling technique where the researchers select samples based on their knowledge and professional judgment [24]. In this true essence, the selection of the barangay was based on the criteria of having moderately vulnerable and had a low level of susceptibility to natural hazards [23]. The sample was selected from the residents living along the coastal area in the Province of Davao del 
Norte, particularly in the coastal communities of Panabo City (Barangay Cagangohan, San Pedro, and J.P Laurel). The informants for the In-depth Interview (IDI) were three (3) informants in each barangay, contributed by nine (6) informal settlers living along with the coastal areas of each barangay.

\subsection{Data Gathering Procedures}

The traditional approach varies from a qualitative approach to data collection, analysis, and interpretation. The interview's data collection should be based on data sources in qualitative study questions [25]. Also, in the qualitative research approach, data collection in qualitative research has four types of categories: participation in the setting, direct observation, informative interview, and document analysis [26].

As the researchers, we are aware that we must undergo crucial steps in data collection, but with a great hope to complete the investigation; the following steps will be followed:

First, the researchers send a letter to ask permission to conduct research to the office of the Dean of the Institute of Leadership, Entrepreneurship and Good Governance of the Davao del Norte State College and wait for its approval.

Second, the researchers must construct and refine the research questions as one of the tools for the guidelines in the interview. After that, we sent it to our chosen qualified validators to validate the research question if appropriate and relevant to our study.

Third, the participants will be identified by using purposeful sampling. The participants would be informed about the study and its primary purpose and ask for their permission for their voluntary participation in the study.

Fourth, the preparation of all materials needed, which included the interview guides and audio recorder.

Fifth, an informative interview will be followed, and documentation through audio-recording, and the data gathered will be transcribed purposely and analyzed thoroughly to identify the dilemmas of the subject.

The data collection was through an informative interview. The purpose of its inclusion was to explore the informants' difficulties and challenges. To gather the significant data needed to answer the research questions of this, we conducted face-to-face interviews. The interview would be documented through audio recordings to ensure the authenticity of the responses and the safekeeping of the information needed. It was suggested that in conducting the study, data must be stored so that they can be easily found and protected from loss and damage [27]. In this study, documented audio and transcriptions should be saved by cloud computing and would be kept safe by the researchers.

Due to the pandemic, the researchers strictly adhered to the health safety protocols for safe data gathering. The interview was done through a physical meet-up. During the interview, the strict observation of the necessary protocols; wearing a face shield and face mask, social distancing, and hand washing before and after the contact with the person were done.

\subsection{Data Analysis}

Since the purpose of the study is to know the living conditions, difficulties and challenges, and coping mechanisms of the informal settlers living along with the coastal areas, it is vital to choose the most appropriate method of data analysis to answer the research questions. The case study involves a detailed explanation of the setting or individuals [28]. In order to analyze the data, the researcher used a deductive approach, which is concerned with "developing a hypothesis or hypotheses based on existing theory, and then designing a research strategy to test the hypothesis" [29].

Consequently, all the collection, correct transcription, and translation of all data from the In-depth Interview (IDI) were recorded. First, answers according to the questions were clustered. Second, substantial and repeated statements per question and dimensions were extracted. Third, codes per similar important statements were assigned. Fourth, the significant statements were classified. Fifth, emerging themes were identified. Finally, the emerging will be grouped according to its structure and patterns according to research questions. The results of the IDI were analyzed, wherein themes were discussed, validated, confirmed, or contested.

\subsection{Ethical Considerations}

The first duty of the researcher is to ensure that the researcher should make the participant no harm. The participant's right to privacy, self-determination, and freedom to withdraw at any time from the study would be considered in this study. In conducting research involving humans as the subject, there must be three basic ethical principles: the principle of respect for persons, beneficence, and justice. Subjects in research should be treated autonomously, and those who have diminished autonomy must be under protection. To acknowledge autonomy and protect who has diminished autonomy are the two divisions of the moral requirements of respect for persons. Beneficence is the obligation of the researcher to secure the well-being of its respondents. "Do not harm, maximize possible benefits and minimize possible harms" are the general rules of beneficent action. While justice means "fairness of distribution" or "what is deserved." All participants should be treated equally, no matter what designation or position acquired [30]. As suggested, before the data collection, we ensured that the involvement of the research participants should be voluntary and that it would not place them at undue risk [31]. Accurate information such as the study's purpose and nature was explained and made clear to the subjects for them to understand. Lastly, this case study underwent intensive scrutiny by the distinguished validators in Davao del Norte State College. 


\section{RESULTS AND DISCUSSIONS}

This section represents the results and discussions of the different answers and standpoints of the participants regarding our study entitled "The Plight of Informal Settlers in the Coastal Areas of Panabo City: A Basis for Intervention." It also includes delving into their challenges, the factor that influences their living conditions along the coastal area. This section presents the interpreted findings generated as a result of the study, which is supplemented with the researcher's perspective and substantiated with literature support and relevant theories. Other than that, implications for practice based on the derived themes during the data analysis were also discussed.

The data gathered has been carefully analyzed and interpreted. Through the inquiry, seven (6) major themes emerged. The result and discussion of the findings are presented below.

\subsection{Challenges of Informal Settlers Living in the Coastal Area}

Out from the personal perspectives of the participants, there are three themes generated as presented in Table 2: Living Condition Predicaments, Environmental Health Risks, and Struggles in Family and Livelihood Instability. The mentioned themes enabled us to report the core ideas which detailed the challenges experienced by informal settlers in the coastal areas.

Table 2. Themes and Core Ideas on the Challenges of Informal Settlers living in the Coastal Areas in Panabo City

\begin{tabular}{|c|c|}
\hline $\begin{array}{c}\text { MAJOR } \\
\text { THEMES }\end{array}$ & CORE IDEAS \\
\hline \multirow{5}{*}{$\begin{array}{l}\text { Living Condition } \\
\text { Predicaments }\end{array}$} & $\begin{array}{l}\text { Our house is not totally safe; it has many damages } \\
\text { and easily destroyed whenever there are big waves } \\
\text { and strong winds. }\end{array}$ \\
\hline & $\begin{array}{l}\text { We don't have a proper comfort room, no proper } \\
\text { sanitation, and a lack of adequate clean water } \\
\text { supply. }\end{array}$ \\
\hline & $\begin{array}{c}\text { Every time there's a calamity or disaster, we're } \\
\text { apprehensive about what might happen to us, and } \\
\text { our lives are at stake due to our risky or dangerous } \\
\text { situations. }\end{array}$ \\
\hline & $\begin{array}{l}\text { Our biggest problem is the storm, the big waves, } \\
\text { and the strong wind, almost all our houses } \\
\text { destroyed. }\end{array}$ \\
\hline & $\begin{array}{l}\text { Every time there are big waves, storms, and } \\
\text { tsunami are what we feared }\end{array}$ \\
\hline \multirow{5}{*}{$\begin{array}{l}\text { Environmental } \\
\text { Health Risks }\end{array}$} & $\begin{array}{l}\text { I felt nervous and afraid, especially when the rain, } \\
\text { waves, and winds got stronger. }\end{array}$ \\
\hline & $\begin{array}{l}\text { We feel worried most of the time, especially for our } \\
\text { children's health; we are worried about what to eat } \\
\text { tomorrow. }\end{array}$ \\
\hline & $\begin{array}{c}\text { We have an allergy and other diseases; sometimes, } \\
\text { we have a fever, cough, and cold. }\end{array}$ \\
\hline & $\begin{array}{l}\text { I feel exhausted due to the difficulties; my mother } \\
\text { got sick, and it took a long time for her to recover. }\end{array}$ \\
\hline & $\begin{array}{l}\text { We usually experience sickness caused by the } \\
\text { masses of garbage brought by the waves, and we } \\
\text { don't have a good lavatory and enough clean water. }\end{array}$ \\
\hline \multirow{2}{*}{$\begin{array}{l}\text { Struggles in } \\
\text { Family and } \\
\text { Livelihood } \\
\text { Instability }\end{array}$} & $\begin{array}{l}\text { We do not have enough fishing material; our boats } \\
\text { are easily broken and small. }\end{array}$ \\
\hline & $\begin{array}{l}\text { I find it hard to earn money; we can't even go } \\
\text { fishing because we do not have a boat. }\end{array}$ \\
\hline
\end{tabular}

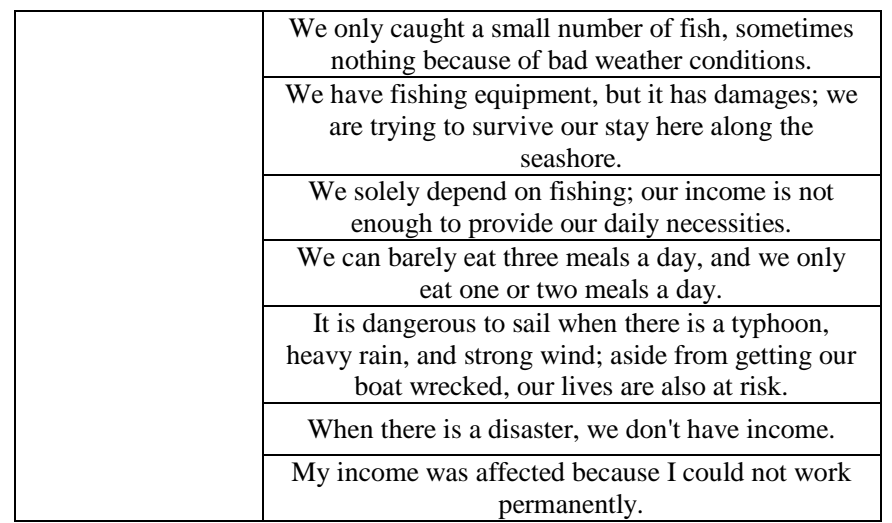

\section{Living Condition Predicaments}

Living life has never been easy for the informal settlers. They experienced different challenges as they lived in the coastal areas. All of the informants shared and expressed the predicaments of their living conditions during the in-depth interview. The study revealed that many aspects affect the ways of life of the informal settlers living in the coastal areas. The majority of the informants shared that their living situations are vulnerable to hazards. They are more vulnerable to both man-made and natural hazards, which cause more casualties and damages. The hard thing they experienced was during the stormy season that brought coastal flooding, big waves, and strong winds wherein most of the houses collapsed or were destroyed. Unfortunately, not all of them receive assistance from the government, as revealed by the informants. Informants pointed out how challenging it is to be an informal settler living in a risky situation. Children and the elderly were found most vulnerable during the cyclone [6].

In the quest to look into the informal settlers' living conditions, it was also found out that another predicament is the low structural quality of shelters as shared by all of the participants. Their houses usually consist of low structural materials that are only made of light materials that are easily ruined when bad weather occurs. They repair the damages caused by the smashed of giant waves on their own.

This result supports the claim in the study of Duyne that informal settlers are more susceptible and exposed to natural disasters than the overall population. They typically live in fragile, improvised shelters in high-risk areas. Because they have only weak or informal tenure, informal settlers receive less housing aid in the aftermath [32].

It was notable as well that the other problem of informal settlers is the lack of access to basic needs such as sources of clean water where they can use for washing, cooking, and drinking. Also, they do not have a proper lavatory or waste disposal, which leads them into unsanitary conditions. Through an in-depth interview, participants shared that they need to walk a long distance to fetch water to use at home. Some of them built their temporary lavatory, but others only used their neighbor's toilets. Because of lack of social and 
economic choices, they tend to live flimsy with poor sanitation. Most of the informants lived in the coastal areas for more than 20 years, but the said problems still exist.

Mankee cited a similar situation that poor sanitation has been a thorny issue in many informal settlements in third world countries, especially in Kenya. Most of the informal settlers still do not have access to clean water and decent sanitation. Even in a pandemic, people need to walk a long distance to collect water to use at home. Most people living in slums also have no choice but to participate in the informal economy. Poor sanitation and contaminated environments have a negative impact on the poor. [34]. Also, various studies show that most informal households do not have enough income to install decent water systems [7]. Despite the mentioned predicaments of their living condition, they still take initiatives as they continue living in the coastal areas.

\section{Environmental Health Risks}

The second major theme in the plight of informal settlers living in the coastal areas in Panabo City is the environmental health risks. The study revealed the informal settlers faced everyday health risks arising from those aforementioned predicaments. It resulted in mental and physical health impairments that affect the parents, children, and even the elderly in the family. Their mental and physical health was affected. Most of the time, the informal settlers get anxious, worried, afraid, and stressed because of their risky living situation or uncomfortable environment even though they lived there for a long time. They feel worried about the security of their families, especially their children. Informants pointed out that they had sleepless nights because they need to observe their surroundings and be vigilant all the time.

This result holds in the study of Satterthwaite that the informal settlers' living environment creates stress, which is the major cause of many psychosocial disorders. Since life and living conditions in informal settlements are so stressful, the danger of stress and subsequent mental conditions is substantial [35]. As documented in the ScienceDaily article, one in six adults in England suffers from mental health disorders such as anxiety and depression. People in poorer households living close to the coast experience fewer symptoms of mental health problems [36].

Not only the mental health of the informal settlers was affected as well as their physical health due to the masses of garbage caused by coastal flooding or even the aftermath of the typhoon, the unsanitary condition, or the unhygienic environment. Most of them, typically affected by a vast array of terrible illnesses, acquire allergies and diseases, particularly their children, as revealed by the participants. It was found out that various residents suffer from health problems like disease, cough, fever, cold, malnutrition, or even injury due to being prone to calamities. Indeed, these revelations of informants are in effect based on the study of Kabir et al. that during and after the natural disaster, children and elderly individuals were identified as being most vulnerable, and most children are also suffering from health problems such as malnutrition. People living in coastal areas lack access to clean water, which has worsened the spread of waterborne diseases in the coastal areas, even though the main 249 sources of infectious diseases are filthy and extremely saline water [6]. Thus, the health of the informal settlers was compromised and put at stake. Slum children and the elderly are more prone to contracting the COVID-19 virus due to a lack of access to safe water and sanitation [37].

\section{Struggles in Family and Livelihood Instability}

Upon analyzing the gathered data, the researchers generated the third emerging theme, which is the struggles in family and livelihood instability. It was found out that the participants encountered and experienced struggles in their families and livelihood. Insufficiency of daily consumption is one of their difficulties in the family. Most of them were struggling with providing food for their daily consumption. Accompanied by that difficulty is the instability of their livelihood or the irregularity of their work due to the different weather conditions and unsafe livelihood equipment. Some of the participants admitted that they barely eat three times a day because of their predicaments that affect their daily lives. Some of them solely depend on fishing as their source of income, and not all the time do they catch a lot of fish because of the lack of fishing equipment and materials as well as due to the unpredictable weather conditions. The aforementioned living predicaments, as shared by the participants, really affect their families and means of living, and that makes it harder for them to provide the basic needs they must have for their families. Most informal settlers are earning below the minimum wage, which makes it challenging to provide formal housing for their families. According to ATD Fourth World Philippines, due to lower income acquired, most of the families barely eat a complete meal in a day [38]. The influx of informal settlements in the waterways of the cities is growing. Most of them resort to fishing to bring food to their tables, but they have no proper tools to be used [39].

\subsection{Coping Mechanisms of the Informal Settlers Living in the Coastal Area.}

Out from the personal perspectives of the informants, there are three themes generated as presented in Table 3: Practicality and Resiliency, Resources Utilization, and Emergency Tactics. The mentioned themes enabled us to report the core ideas which detailed the coping mechanism applied by informal settlers in the coastal areas.

Table 3: Themes and Core ideas on the Coping Mechanisms Living in the Coastal Area in Panabo City

\begin{tabular}{|c|c|}
\hline Major Themes & Core Ideas \\
\hline \multirow{2}{*}{$\begin{array}{c}\text { Practicality and } \\
\text { Resiliency }\end{array}$} & $\begin{array}{c}\text { We are the only ones working hard to repair our } \\
\text { damaged house. }\end{array}$ \\
\cline { 2 - 2 } & $\begin{array}{c}\text { moments of comfort, but we are mainly facing } \\
\text { struggles. }\end{array}$ \\
\cline { 2 - 2 } & $\begin{array}{c}\text { We chose to put our stuff in the higher part of the } \\
\text { house, away from the water. }\end{array}$ \\
\hline
\end{tabular}




\begin{tabular}{|c|c|}
\hline & $\begin{array}{c}\text { If there is a typhoon, we will evacuate to a safer } \\
\text { place. }\end{array}$ \\
\hline & $\begin{array}{c}\text { During heavy rains or storms, our hut is destroyed, } \\
\text { and we rebuild it }\end{array}$ \\
\hline \multirow{6}{*}{$\begin{array}{l}\text { Resources } \\
\text { Utilization }\end{array}$} & Fishing as a secondary source of income. \\
\hline & $\begin{array}{l}\text { Near to the source of income which is the market } \\
\text { and gleans for viand. }\end{array}$ \\
\hline & Save electricity as benefited by the fresh air. \\
\hline & $\begin{array}{c}\text { Fishing as the main source of income and large scale } \\
\text { of area in fishing }\end{array}$ \\
\hline & Near our livelihood, we are gleaning then selling it. \\
\hline & $\begin{array}{l}\text { We get fresh air which is a good benefit since we no } \\
\text { longer need electric fans because it is already cold } \\
\text { here. }\end{array}$ \\
\hline \multirow{5}{*}{$\begin{array}{l}\text { Emergency } \\
\text { Tactics }\end{array}$} & Ask for financial aid to meet the needs. \\
\hline & $\begin{array}{l}\text { we should always be ready; we need to bring and } \\
\text { secure if ever they inform us to evacuate, and we'll } \\
\text { wait for the information they disseminate }\end{array}$ \\
\hline & Depend on debt to sustain a better life \\
\hline & Sometimes it's hard, but we never give up. \\
\hline & Go to a safer place \\
\hline
\end{tabular}

\section{Practicality and Resiliency}

In dealing with the challenges, informal settlers developed practical skills to become resilient in coping with the challenges. Self-resiliency potentially develops and promotes individual focus on the stage of preparedness, response, and recovery from climate risk [40]. Upgrading informal settlement, especially in dealing with disaster mitigation, has not been fully implemented in the country.

The study revealed that most of the participants shared that they resorted to being self-organized through repairing their own houses and other things that they can still use. In the fact that they are vulnerable to natural hazards, they still manage to continue living by fixing their own house as it was damaged due to heavy rain and strong wind or storm. Informal settlers were often associated with resourcefulness and innovativeness. The participants also shared that they initiate themselves to evacuate into a safer place if there is a typhoon. Esser makes a stand that informal settlers are often self-reliant and prudent to their surroundings even though they are at risk as long as they see some advantageous aspect on a certain area they reside, they will stay [41].

\section{Resources Utilization}

The study revealed that most of the participants' source of income is fishing. It was revealed that it is their main source of income, and their place has a large scale of area in fishing. Aghazadeh stated that fishing is the main occupation of fishermen who lives along the shores [42]. Participants also shared since they are settling along the coastal area, it is easy for them to make a living through fishing. Aside from the strategy just to be able to survive, living in that place helped them to solve some problems. Living along the seaside is quietly a big advantage to them also.

As time passes, the seawater is rising due to global warming and climate change, and coastal communities are primarily affected by it. Some of them migrated to avoid further losses and damages. Others refused to be relocated because it is near to their livelihood or they cannot afford formal housing. Informal settlers usually resort to the sea to get food to sustain their family [43]. All the informants said that they find coastal settling refreshing due to the breeze brought by the sea.

\section{Emergency Tactics}

Informal settlers were unconsciously driven to areas that are unsuitable for housing, which is exposed informal settlers to a vicious repeating cycle of destruction and loss of life [44]. In the study context, the family living in the coastal area is not also focusing on that matter only. In terms of coping mechanisms, they usually depend on debt to sustain their basic needs.

When it comes to difficulty, the health problem is also a big crisis to them. Being sick is one of the biggest problems for them. When those times come, they will ask the Barangay for financial help. As natural hazard is the most common emergency problem leaving the coastal area, participants stated that when high tide, they will evacuate to a high area to stay safe. Also, they are cautious and compliant with the government's advice.

Despite facing the uncontrollable problems of living in a slum area, informal settlers ask the LGU for extra assistance to improve their shelter [45]. Suffering from poverty is also a cause of having difficulty meeting their needs. They seek help from the Government as it plays a vital role [46].

\subsection{Government Interventions in Addressing the Challenges of Informal Settlers Living in the Coastal Area}

The presented table below is the intervention plan derived from the analyses of this study in responding to the problems of informal settlements in the coastal area.

Table 4. Intervention Plan

\begin{tabular}{|c|c|c|c|c|c|c|c|}
\hline \multirow{2}{*}{ Problems } & \multirow{2}{*}{ Objectives } & \multirow{2}{*}{ Content } & \multicolumn{2}{|c|}{ Strategies/Activities } & \multirow{2}{*}{ Time Frame } & \multicolumn{2}{|c|}{ Persons Involved } \\
\hline & & & Mode & $\begin{array}{l}\text { Resources } \\
\text { Needed }\end{array}$ & & Target Group & Responsible \\
\hline $\begin{array}{l}\text { Vulnerability to } \\
\text { Hazards. }\end{array}$ & $\begin{array}{c}\text { To mitigate } \\
\text { damages and } \\
\text { losses brought } \\
\text { by various } \\
\text { hazards }\end{array}$ & \begin{tabular}{|c|} 
Crisis \\
Management \\
and \\
Emergency \\
Response \\
Training
\end{tabular} & $\begin{array}{c}\text { Seminar and } \\
\text { Training }\end{array}$ & $\begin{array}{c}\text { Resource } \\
\text { person, venue, } \\
\text { meals and } \\
\text { supplies }\end{array}$ & $\begin{array}{c}\text { August } \\
2021\end{array}$ & $\begin{array}{c}\text { Informal } \\
\text { Settlers Living } \\
\text { in the Coastal } \\
\text { Area }\end{array}$ & \begin{tabular}{|c} 
Designated \\
Lacal \\
Government Unit \\
and Selected \\
National \\
Agencies
\end{tabular} \\
\hline $\begin{array}{c}\text { Lack of } \\
\text { Access to } \\
\text { Basic Needs }\end{array}$ & $\begin{array}{l}\text { To provide } \\
\text { access to } \\
\text { basic needs }\end{array}$ & $\begin{array}{l}\text { Magna Carta } \\
\text { of the Poor }\end{array}$ & $\begin{array}{c}\text { Seminar and } \\
\text { Training }\end{array}$ & $\begin{array}{l}\text { Resource } \\
\text { person, venue, } \\
\text { meals and } \\
\text { supplies }\end{array}$ & October 2021 & $\begin{array}{c}\text { Informal } \\
\text { Settlers Living } \\
\text { in the Coastal } \\
\text { Area }\end{array}$ & \begin{tabular}{|c} 
Designated \\
Local \\
Government Unit \\
and Selected \\
National \\
Agencies
\end{tabular} \\
\hline $\begin{array}{l}\text { Unhygienic } \\
\text { Environment }\end{array}$ & $\begin{array}{c}\text { To make their } \\
\text { environment } \\
\text { suitable for } \\
\text { habitation }\end{array}$ & $\begin{array}{c}\text { Department of } \\
\text { Health (Poor } \\
\text { hygiene and } \\
\text { disease) }\end{array}$ & $\begin{array}{c}\text { Seminar and } \\
\text { Training }\end{array}$ & $\begin{array}{c}\text { Resource } \\
\text { person, venue, } \\
\text { meals and } \\
\text { supplies }\end{array}$ & $\begin{array}{l}\text { November } \\
2021\end{array}$ & $\begin{array}{c}\text { Informal } \\
\text { Settlers Living } \\
\text { in the Coastal } \\
\text { Area }\end{array}$ & \begin{tabular}{|c} 
Designated \\
Lacal \\
Government Unit \\
and Selected \\
National \\
Agencies
\end{tabular} \\
\hline $\begin{array}{l}\text { Livelihood } \\
\text { Instability }\end{array}$ & $\begin{array}{l}\text { To subsidize } \\
\text { livelihood }\end{array}$ & $\begin{array}{l}\text { Social Reform } \\
\text { and Paverty } \\
\text { Alleviation Act }\end{array}$ & $\begin{array}{l}\text { Seminar and } \\
\text { Training }\end{array}$ & $\begin{array}{l}\text { Resource } \\
\text { person, venue, } \\
\text { meals and } \\
\text { supplies }\end{array}$ & $\begin{array}{l}\text { December } \\
2021\end{array}$ & $\begin{array}{c}\text { Informal } \\
\text { Settlers Living } \\
\text { in the Coastal } \\
\text { Area }\end{array}$ & $\begin{array}{c}\text { Designated } \\
\text { Lacal } \\
\text { Government Unit } \\
\text { and Selected } \\
\text { National } \\
\text { Agencies }\end{array}$ \\
\hline $\begin{array}{l}\text { Poor Quality } \\
\text { Shelters }\end{array}$ & $\begin{array}{l}\text { To provide } \\
\text { shelters } \\
\text { suitable for } \\
\text { habitation with } \\
\text { adherence to } \\
\text { the building } \\
\text { the standards }\end{array}$ & $\begin{array}{c}\text { National } \\
\text { Building Code } \\
\text { of the } \\
\text { Philippines }\end{array}$ & $\begin{array}{l}\text { Relocation and } \\
\text { Subsidy on } \\
\text { Construction } \\
\text { Materials }\end{array}$ & $\begin{array}{l}\text { Designated } \\
\text { Local } \\
\text { Government } \\
\text { Unit (Selected } \\
\text { Offices), } \\
\text { venue, } \\
\text { materials and } \\
\text { equipment's }\end{array}$ & 2021-2026 & $\begin{array}{c}\text { Informal } \\
\text { Settlers Living } \\
\text { in the Coastal } \\
\text { Area }\end{array}$ & $\begin{array}{c}\text { Designated } \\
\text { Lacal } \\
\text { Government Unit } \\
\text { and Selected } \\
\text { National } \\
\text { Agencies }\end{array}$ \\
\hline
\end{tabular}




\subsection{Implication for Practice}

Local Government Units are supposed to provide housing units for the informal settlers. With the collaboration of the National Housing Authority, they shall ensure relocation and resettlement sites for the informal settlers as stated in the Local Government Code of the Philippines. Despite that provision of the law, there are still numerous failures in relocating people from the slums. They still go back to slums because, for them, there are more opportunities in terms of their livelihood compared to staying at the relocation sites provided. It is more adjacent to their jobs and other sources of income [47]. There are many laws in the country governing how establishments and buildings should adhere. The provision's scope is the construction and maintenance of residential, industrial, commercial, and recreational establishments in the country. Yet informal settlements are not adhering nor comply with the provisions. Most of their houses are made of light materials and vulnerable to disasters, prone to fire, and can be easily devastated [48]. The acknowledgment of the existence of informal settlements by the government seems hard. The slums continuously economically, geographically, politically, and socially disengaged from decision-making and urban opportunities [49].

\subsection{Concluding Remarks}

The informal settlement is one of the major problems in the country. They are exposed and prone to different hazards, which cause more casualties and damages. Most of them are living in an unhygienic environment that could lead to various ailments. Their houses usually consisted of low structural materials. Due to unstable livelihood and other sources of income, some of them are struggling to provide food and other necessities every day. Despite a perilous environment, their influx is getting greater, mainly at the waterways of the cities, especially in the coastal areas. Throughout the time, they developed skills and strategies to cope with the challenges to survive. Most of them coined, living in the coastal area is more accessible for their livelihood and adjacent to various places for their necessities, even though their houses are situated in a land not owned by them. Despite being vulnerable to disasters, they still find ways to cope and survive. Most of them are self-reliant. They build and repair their own houses if wreckage comes. But it is still inevitable that some challenges are beyond their capabilities. There are some stories behind that the government did not. Thus, some of them are not subsidized and continue to strive on their own.

\section{ACKNOWLEDGEMENT}

We would like to extend our heartfelt gratitude and appreciation to the following individuals and entities whose generous support and cooperation made the writing of the study possible. To Hon. Osmundo Micabani, the Barangay Captain of Barangay Cagangohan, Hon. Richard Okay, Barangay Captain of JP. Laurel, Hon. Edwin S. Olita Sr., Barangay Captain of San Pedro Panabo City, Davao del Norte, for allowing us to conduct this study in their respected barangays and for their warm accommodation during the conduct of this study. To the contributors of this research, for the unending support and sharing their knowledge, thoughts, and ideas in helping us complete our research paper. Above all, to the Almighty Father, for His unconditional love and for making all these things possible.

\section{REFERENCES}

[1] Inner City Fund International (2014). Developing a National Informal Settlements Upgrading Strategy of the Philippines. Final Report. Retrieved on 12th September 2019 from http://www.hudcc.gov.ph.pdf

[2] Srinivas, H. (2015). Urban Squatters and Slums, Defining Squatter Settlements. Retrieved from https://www.gdrc.org/uem/squatters/define-squatter.html

[3] McCallian, B., \& Scherer, I. (2015). Urban informal settlers displaced by disasters: challenges to housing responses. Retrieved fromhttp://www.internaldisplacement.org/sites/default/files/public ations/documents/201506-global-urban-informal-settlers.pdf

[4] Beall, J., \& Fox, S. (2007). Urban Poverty and Development in the $21^{\text {st }}$ Century. Retrieved on $14^{\text {th }}$ of January 2020 from http://eprints.lse.ac.uk/2903/1/urban_poverty_and_development_in _the_21st_century.pdf

[5] World Ocean Review (2010). Living with the Oceans. A Report on the State of the World's Oceans, p.1. Retrieved on $25^{\text {th }}$ August 2019 from https://worldoceanreview.com/en/wor-1/coasts/livingin-coastal-areas/

[6] Kabir M. L., et al., (2016, March 15). Knowledge and perception about climate change and human health: findings from a baseline survey among vulnerable communities in Bangladesh. Retrieved on 25th of April 2021 from https://bmcpublichealth.biomedcentral.com/articles/10.1186/s1288 9-016-2930-3

[7] Participatory Research in Asia. (2013, November). Contribution of Urban Informal Settlement Dwellers to Urban Economy in India. 42 Tughlakabad Institutional Area, New Delhi. Retrieved from https://www.pria.org/engaged-citizens-responsive-city

[8] Rahman, M. and Amanulla. A (2011). Access to Land and Location of Informal Settlements in Tacloban City, Philippines. Retrieved https://www.researchergate.net/publication/290437827

[9] Enriquez, K. (2017). High Ground: Disaster Risk and Resilience in the Philippines. Retrieved from https://www.preventionweb.net/news/view/59076

[10] Coastal Resources Management-Technical Working Group (2006). Davao City Coastal Zone Management Situation and Recommendations. "Solid Waste and Wastewater." Issues and problems, $10 . \quad$ Retrieved from https://www.scribd.com/document/338172547

[11] De Ungria, R. (n.d). Housing for the poor, The SANPASADA Experience. Retrieved from http://www.pcpd.ph/uploads/ publications/65people\%20and\%20housing1.pdf

[12] Lagmay et al., (2013, February 09). How debris buried Compostella village. Inquirer.net. Retrieved from https://opinion.inquirer.net/46563/how-debris-buried-compostelavillage

[13] Brown, (2002). Politeness Strategies - a theoretical framework: Sociolinguistic observations of politeness Retrieved from http://hig.divaportal.org/smash/record.jsf?pid=diva2\%3A565250\& dswid=-739

[14] Republic Act No. 7161: GOVPH. Official Gazette of the Republic of the Philippines. (1991, October 10). Retrieved from https://www.officialgazette.gov.ph/1991/10/10/republic-act-no$7161 /$.

[15] Urban development and Housing act of 1992 (Republic Act NO. 7279). (n.d.). Retrieved from https://urbanlex.unhabitat.org/law/152 
[16] Attorney, P. (2016, March 7). Urban development and Housing act Of 1992: A misunderstood law?. Retrieved from https://attorney.org.ph/legal-news/92-urban-development-andhousing-act-of-1992-a-misunderstood-law.

[17] Creswell, J.W. (2014). Qualitative Inquiry \& Research Design: Third Edition. Retrieved from http://www.ceilconicet.gov.ar/wpcontent/uploads/2018/04/CRES WELLQualitative-Inquary-and-Research-Design-Creswell.pdf

[18] Denzin N.K. \& Lincoln Y.K. (2005). In The Sage Handbook of Qualitative Research. Third Edition. pp. 10. Thousand Oaks, California.

[19] Creswell, J. W. (2012). Qualitative Inquiry and Research Design: Choosing Among Five Approaches. Retrieved from https://books.google.com.ph/books?id=OJYEbDtkxq8C\&pg=PA6 $9 \&$ source $=$ gbs_toc_r\&cad $=3 \# \mathrm{v}=$ onepage $\& \mathrm{q} \& \mathrm{f}=$ false

[20] Baxter, P.E, \& Jack, S. (2010, January). Qualitative Case Study Methodology: Study Design and Implementation for Novice Researchers. Retrieved on 25th of November from https://www.researchgate.net/publication/228621600_Qualitative Case_Study_Methodology_Study_Design_and_Implementation for_Novice_Researchers

[21] Patton, M. (1990). Qualitative Evaluation and Research Methods (pp. 169-186). Retrieved on $25^{\text {th }}$ of November from https://legacy.oise.utoronto.ca/research/fieldcentres/ross/ctl1014/P atton1990.pdf

[22] Philippine Statistics Authority (2018). 2018 Philippine Standard Geographic Code (PSGC). Retrieved from https://psa.gov.ph/classification/psgc/?q=psgc/citimuni/112300000

[23] Jocson, M. \& Magallon, S. (2018, January). Coastal Vulnerability Assessment: The Case of Davao del Norte, Phil. Retrieved from https://www.researchgate.net/publication/331074824_Coastal_Vul nerability_Assessment_The_Case_of_Davao_del_Norte_Philippin es.

[24] Yaya, J. (2014, June). A Comprehensive Guide to Research Methodology (part 1): tips for sampling and sample techniques. Retrieved from https://nairaproject.com/blog/step-by-step-toresearch-methodology.html

[25] Creswell, J.W. (2013). Qualitative Inquiry \&Research Design: Choosing Among the Five Approaches. Retrieved from https://blogs.baruch.cuny.edu/com9640epstein/?p=543

[26] Creswell, J. W. (2007). Collecting data in Mixed Methods Research. Retrieved from https://www.sagepub.com/sites/default/files/upmbinaries/10983_C hapter_6.pdf

[27] Creswell, J.W. (2013). Qualitative Inquiry \&Research Design: Choosing Among the Five Approaches (3rd ed.). Los Angeles: Sage. (pp. 448-147). Chapter 7. Data Collection. Retrieved from http://www.ceil-conicet.gov.ar/wpcontent/uploads/2018/04/CRESWELLQualitative-Inquary-andResearch-Design-Creswell.pdf

[28] Creswell, J. (2009). Research design: Qualitative, quantitative, and mixed methods approaches (3rd ed.). Los Angeles: Sage. Retrieved from https://gdaviesedd.wordpress.com/2015/10/05/fivemethods-of-qualitative-research-creswell-2009/

[29] Wilson, J. (2010). Essentials of Business Research: A Guide to Doing Your Research Project. p.7. Retrieved from http://researchmethodology/research-approach/deductive-approach-2/

[30] Office for Human Research Protections (OHRP). (2018, January 15). Read the Belmont Report. HHS.gov. Retrieved from https://www.hhs.gov/ohrp/regulations-and-policy/belmontreport/read-the-belmont-report/index.html.

[31] Creswell, J.W. (2013). Qualitative Inquiry \&Research Design: Choosing Among the Five Approaches (3rd ed.). Los Angeles: Sage. (pp. 448-57). Chapter 3. Designing a Qualitative Study, Retrieved from http://www.ceil-conicet.gov.ar/wpcontent/uploads/2018/04/CRESWELLQualitative-Inquary-andResearch-Design-Creswell.pdf

[32] Duyne, J. (2015). Urban Informal Settlers Displaced by Disasters: Challenges to Housing Responses. Retrieved from https://www.internaldisplacement.org/sites/default/files/publicatio ns/documents/201506-global-urban-informal-settlers.pdf
[33] Gonzales, P. \& Zerbo, A. (2020) Vulnerability and Everyday Health Risks of Urban Informal Settlements in SubSaharan Africa. Global Health Journal, (4)2, 46-50. Retrieved from https://www.sciencedirect.com/article//pii/S241464472030021X

[34] Manke, K. (2020, May 21). Urban slums are uniquely vulnerable to COVID-19. Here's how to help. Berkeley News. https://news.berkeley.edu/2020/04/27/urban-slums-are-uniquelyvulnerable-to-covid-19-heres-how-to-help/.

[35] Satterthwaite, D. (1993). The Impact on Healthy Urban Environments. Retrieved from SAGE Journals. https://journals.sagepub.com/doi/abs/10.1177/0956247893005002 08 .

[36] ScienceDaily. (2019). Coastal Living Linked with Better Mental Health. Retrieved from ScienceDaily. https://www.sciencedaily.com/releases/2019/09/190930214514.ht $\mathrm{m}$

[37] Ki, C.O. (2020). Children in Informal Settlements Have Higher Health Risks, Says Group. Manila Bulletin. Retrieved from https://www.google.com/amp/s/mb.com.ph/2020/10/05/childrenin-informal-settlements-have-higher-health-risk-saysgroup/\%3famp

[38] Ballesteros, M. (2010). Linking Poverty and the Environment: Evidence from Slums in Philippine Cities. Philippine Institute for Development Studies. Discussion Paper Series No. 2010-33.

[39] ATD Fourth World (2015). Partners in Development: Listening to the Voices of Families Living in Extreme Poverty. contribution to the post 2015 Sustainable Development Agenda. 1225 Laborers Street, 1011 Pandacan, Manila.

[40] Busayo, E. T., \& Kalumba, A. M. (2020). Recommendations for linking climate change adaptation and disaster risk reduction in urban coastal zones: Lessons from East London, South Africa. Ocean\& Coastal Management. https://www.sciencedirect.com/science/article/abs/pii/S096456912 0303616.

[41] Esser, G. (2015). Some Place of Vulnerability: Exploring Home and Resettlement of River-Fronting Informal Settlers Using Narrative and Images. The Faculty of Graduate and Predoctoral Studies. The University of British Columbia, Vancouver.

[42] AGHAZADEH, E. (April, 1994). Fisheries Socio-Economic Analysis and Policy. http://www.fao.org/3/ac385e/AC385E00.htm\#TOC

[43] Cain, A. (2014). Informal Settlements in Urban Coastal Zones and Adaptation to Climatic Variation. Regional Development Dialogue. 35(34).

[44] Emergency Management. (2013). Informal Settlers And Disasters. Informal Settlers and Disasters. http://em.fsu.edu/researchinformal.php.

[45] Velasco M. (2016). Examining Stakeholders Collaboration: A case of Relocating Informal Settlers. Retrieved on June 23, 2021, from https://dlsu.edu.ph>LCSPDF

[46] Domingo, S. \& Manejar, A. (2018). Disaster Preparedness and Local Governance in the Philippines. Retrieved from https://pidswebs.pids.gov.ph

[47] Castelo, M. (2018). Manila's Informal Settlers Face Relocation in Exchange for Clean Bay. Conservation News. Retrieved from https://www.google.com/amp/s/news.mongabay.com/2019/10/man ilas-informal-settlers-face-relocation-in-exchange-for-cleanbay/amp/

[48] UNDP (2019). Overview of Internal Migration in Philippines. United Nations. Policies Briefs Southeast Asia.

[49] UN-Habitat (2015). Global Report 2015: Increasing Synergy for Greater National Ownership. United Nations Human Settlements Programme. 